\title{
Foraging behaviour of satellite-tracked king penguins in relation to sea-surface temperatures obtained by satellite telemetry at Crozet Archipelago, a study during three austral summers
}

\author{
Christophe Guinet ${ }^{1, *}$, Malik Koudil ${ }^{2}$, Charles André Bost ${ }^{3}$, Jean Pierre Durbec ${ }^{2}$, \\ Jean Yves Georges ${ }^{1}$, Marie Catherine Mouchot ${ }^{4}$, Pierre Jouventin ${ }^{1}$ \\ ${ }^{1}$ Centre d'Etudes Biologiques de Chizé, Centre National de la Recherche Scientifique, F-79360 Beauvoir sur Niort, France \\ ${ }^{2}$ Centre d'Oceanologie de Marseille, Campus de Luminy, Case 901, F-13288 Marseille Cedex 9, France \\ ${ }^{3}$ Centre d'Ecologie et de Physiologie Energétiques, Centre National de la Recherche Scientifique, 23 rue Becquerel, \\ F-67087 Strasbourg, France \\ ${ }^{4}$ Ecole Nationale Supérieure des Télécommunications, BP 34, F-29285 Brest Cedex, France
}

\begin{abstract}
We investıgated the foraging behaviour of king penguins in relation to sea-surface temperature distribution over 3 years near the Crozet Archipelago, South Indian Ocean. Withın their range there are 2 hydrographic frontal systems, whose seasonal patterns of productivity are predictable. These are the Polar Front and the Sub-Antarctic Front. During the austral summer the foraging range af breeding king penguins was restricted to the Polar Frontal Zone, limited to the south by the Polar Front and to the north by the Sub-Antarctic Front. Most birds travelled towards the colder water situated south of Crozet, while other birds moved east to warmer water. Birds travelling south spent more time than expected in the coldest waters generally associated with the Polar Front. Birds travelling east reached the southern limit of the Sub-Antarctic Front (sea-surface temperature between 8 and $10^{\circ} \mathrm{C}$ ). Within the Polar Frontal Zone birds differed in their foraging behaviour, with incubating birds remaining at sea for longer times and covering longer distances. During the incubation period, king penguins travelling south tended to spend their time in areas with a sea-surface temperature between 4 and $5^{\circ} \mathrm{C}$, which coincide with the location of the Polar Front. Though these birds remained at sea longer, they did not go any further south than birds having an egg ready to hatch or than birds in the brooding period, which appeared to travel more directly towards the Polar Front. As the breeding season progressed, the Polar Front moved further south, out of the range of the king penguins especially those with a newly hatched chick that were limited in the amount of time that they could spend at sea. King penguins breeding at Crozet may choose between 2 strategies, in which some birds forage towards the SubAntarctic Front but most travel south towards the Polar Front.
\end{abstract}

KEY WORDS: Sea-surface temperature King penguins Southern Ocean Foraging Biotelemetry Remote sensing

\section{INTRODUCTION}

Seabirds have heavy energy requirements, suggesting that they should focus on patches of high prey availability (Abrams 1985a, Hunt 1990, 1991). Within the ocean, resources are heterogeneous in distribution

·E-mail: guinet@cebc.cnrs.fr and can be related to physical constraints such as currents, fronts and ice boundaries (Ainley \& Jacobs 1981, Abrams 1985b, Hunt 1990, 1991). Several studies have also shown that the distribution of seabirds in the Southern Ocean could be related to the ocean's spatial heterogeneity and it is known that seabirds could be distributed in relation to the sea-surface temperature, signature of frontal systems (Abrams 1985b, Stahl et al 
1985), and to the vertical stability of water column (Hunt 1990) and the steepness of the surface gradients (Elphick \& Hunt 1993)

Seabirds may also forage in different areas according to their breeding stage (Hunt et al. 1992). During the breeding period, the major constraint on seabirds is the requirement to return to the colony to incubate the egg and to rear the chick. These birds must therefore find their food within a range which is limited by parameters such as aptitudes for flying, swimming and diving as well as by physiological limits such as the ability of the adult to fast and the needs of the growing chick.

Until recently, studies of the pelagic distribution of seabirds were mainly conducted from ships over defined transects. The geographical origin, sex, age and reproductive stage of the birds were generally not known (Abrams 1985b, Stahl et al. 1985, Hunt et al. 1992, Pakhomov \& McQuaid 1996). Satellite tracking now makes it possible to follow seabirds of known colonies and breeding status.

In the present study we relate the foraging behaviour of individually known king penguins Aptenodytes paptagonicus breeding on Possession Island $\left(46.42^{\circ} \mathrm{S}\right.$, $51.90^{\circ} \mathrm{E}$ ) to oceanographic parameters. An estimated 1000000 pairs of king penguins breed on the Crozet Archipelago, south-west Indian Ocean (Guinet et al.
1995), and their annual food consumption is about $0.8 x$ $10^{6} \mathrm{t}$, of which 85 to $90 \%$ is myctophid fish (Guinet et al. 1996). The pelagic distribution of king penguins was first investigated at Crozet Archipelago in 1992 using the Argos satellite tracking technique (Jouventin et al. 1994); during the austral summer, king penguins were found to forage mainly in a southward direction, reaching the latitude at which the Polar Front was generally located. Here, we attempt to answer the questions of whether their foraging range can be precisely related to the distribution of water masses, and whether they prefer to forage in areas of particular sea surface temperature.

Physical oceanographic studies on this sector of the Southern Ocean have established the general distribution of water masses (Fig. 1) (Gamberoni et al. 1982, Park et al. 1991). A north-south transect close to Crozet Archipelago will show the following distribution of the water masses: The Transition Frontal Zone between $40^{\circ}$ and $43^{\circ} \mathrm{S}$ which separates the subtropical waters from the Antarctic waters is extremely narrow $(<200 \mathrm{~km})$ in the Crozet Basin (Gamberoni et al. 1982, Park et al. 1991). This zone is characterised by a strong thermal gradient and delimited to the north by the Sub-Tropical Front, with sea surface temperatures between 17.9 and $14.2^{\circ} \mathrm{C}$, and to the south by the Sub-Antarctic Front,

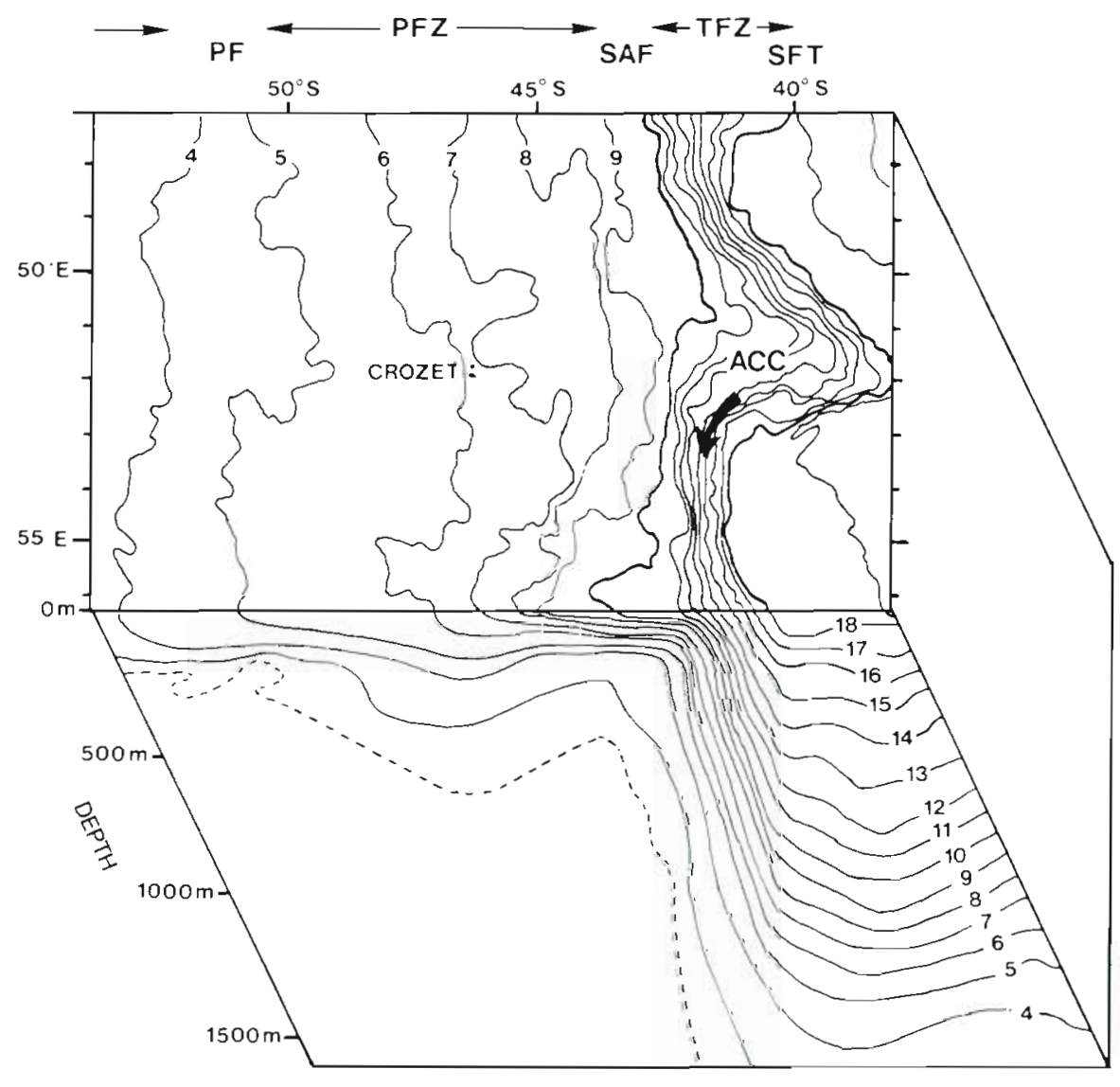

Fig. 1. Study area and oceanographic context according to the sea-surface temperature $\left({ }^{\circ} \mathrm{C}\right)$ obtained through satellite remote sensing (19 to 27 January 1993) and the temperature profile from Park et al. (1993). PF: Polar Front; PFZ: Polar Frontal Zone; SAF: SubAntarctic Front; STF: Sub-Tropical Front; TFZ: Transition Frontal Zone; ACC: Antarctic Circum-Current 
with sea-surface temperatures between 9 and $7^{\circ} \mathrm{C}$; these 2 fronts almost merge in this region (Gamberoni et al. 1982, Park et al. 1991). Further south the Polar Front is located close to $50^{\circ} 30^{\prime} \mathrm{S}$ in April-May (Park et al. 1993), and characterises the northern limit of Antarctic surface water. The 4 to $5^{\circ} \mathrm{C}$ surface isotherm coincides with the location of the Polar Front (Machida 1976, Park et al. 1993), which is defined by the $2^{\circ} \mathrm{C}$ isotherm at $200 \mathrm{~m}$ (Deacon 1982). The Polar Frontal Zone between the Sub-Antarctic Front and the Polar Front is abnormally wide in this sector (Fig. 1).

There is considerable year-to-year variation in the position and structure of the oceanic fronts in the Indian sector of the Southern Ocean (Nagata et al. 1988). Thus one difficulty of studying marine birds at sea in relation to oceanographic conditions is to obtain contemporaneous information. In the abscence of information on oceanographic conditions obtained from ships we used sea-surface temperature distributions from satellite remote sensing. Satellite sensors have repeatedly confirmed that the ocean environment is highly structured, and permit detection of frontal zones of high productivity (Thomas \& Emery 1988, Power \& Nelson May 1991).

The present paper reports the first part of a 3 yr study on the foraging ecology of king penguins at Crozet Islands (see Bost et al. 1997, accompanying paper).

\section{MATERIALS AND METHODS}

Twenty king penguins on Possession Island were fitted with Argos transmitters (Toyocom T2038, Tokyo, Japan; weight $208 \mathrm{~g}, 1.5 \%$ of the body weight of penguins, with a cross-sectional area of $7 \mathrm{~cm}^{2}$ ) over the austral summers of 1992, 1993 and 1994 (see Table 1). These transmitters were attached with quick-set epoxy resin or cable ties which were subsequently cut to recover the devices. Location data were analysed using ELSA software (Argos CLS, Toulouse, France). Four classes of location were received with the Argos system with the following accuracy: class 3, accuracy $150 \mathrm{~m}$; class 2, accuracy $350 \mathrm{~m}$; class 1 , accuracy $1 \mathrm{~km}$; class 0 , quality of the results to be determined by the user. Class 0 locations were filtered to remove aberrant data (Kooyman \& Davis 1987). Kooyman \& Davis (1987) indicated that the mean maximum swimming velocity of a king penguin was $14 \mathrm{~km} \mathrm{~h}^{-1}$, and therefore data giving an average swimming speed higher than $14 \mathrm{~km}$ $\mathrm{h}^{-1}$ were rejected. For this study we adopted the same working hypothesis as Weavers (1992) that between 2 data points king penguins travel in a straight line with a constant speed. When more than $24 \mathrm{~h}$ separated 2 points, data were not included in the statistical analysis. For each penguin we calculated the trip duration, the distance covered, the maximum range, the elonga- tion coefficient (maximum range divided by the distance covered), the minimum and maximum latitude and longitude reached as well as the minimum and maximum sea surface temperature encountered. When data were incomplete due to battery failure or insufficient satellite locations, the duration of foraging was determined from the king penguin's observed date of return to shore, while the total distance covered was taken as a direct line from the last point obtained after the king penguin had turned back towards the colony

Using the above criteria it was possible to estimate the time spent within a defined sector for 14 out of the 20 birds. This approach allowed an explicit graphic representation of the use of different sectors relative to the total duration of the foraging trip (see Bost et al 1997). It was not possible to estimate the time spent per sector for 6 birds due either to an insufficient number of satellite locations $(1095-2,1095-3,2850-3)$ or to battery failure (1095-1, 2850-2, 315-1).

Maps of the sea surface temperature during the study were obtained from the Global Area Coverage (GAC) system of the National Oceanic and Atmospheric Administration (NOAA, Ashevile, NC, USA) One image from the AVHRR/2 (Advanced Very High Resolution Radiometer) of the NOAA 11 satellite with a $4 \times 4 \mathrm{~km}$ resolution was obtained over Possession Island on 7 January 1992 on a clear day while king penguins 1176 and 1051 were at sea. Temperature measurements were also obtained from the same sensor but with a $8 \times 8 \mathrm{~km}$ resolution. To allow for cloud cover, data were obtained every day for a week. The mapped area was established by linear interpolation using SAS software and then treated using MIDAS (Munich Image Data Analysis System, Munich, Germany) to obtain sea-surface temperature plots (see Fig. 2). When the foraging period of the penguins extended over $2 \mathrm{wk}$, data were combined.

Sea surface temperatures were extracted for the tracks of the 14 birds having complete foraging trips and enough satellite locations to estimate the time spent per sector

To verify data obtained from the satellite, we referred to the work of Weimerskirch et al. (1995). In 1994, in situ data were obtained using temperature recorders carried by wandering albatrosses Diomedea exulans tracked by satellite. The data gave a very good correlation $\left(r^{2}=0.97, n=166\right)$ with the data from the satellite (Weimerskirch et al. 1995).

To investigate the relationship between the distribution of king penguins and the sea surface temperature it was necessary to calculate the proportionate areas characterised by each temperature range. The total area was a parallelogram having its limits parallel to latitude and longitude and determined by the minimum and maximum longitude and latitude reached by king penguins 

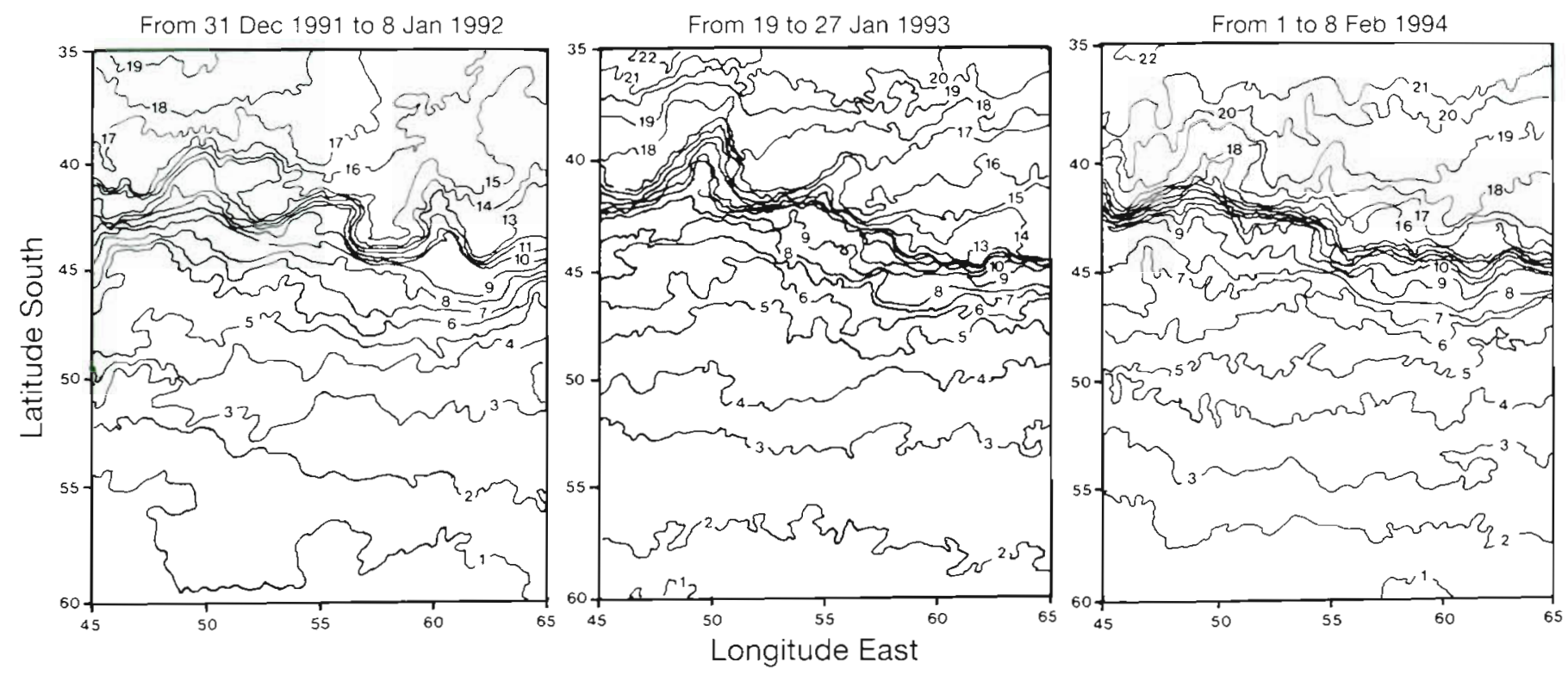

Fig. 2. Isothermal diagram $\left({ }^{\circ} \mathrm{C}\right)$ of sea-surface temperature during the study period

travelling to colder water for each of the 3 years. The area was divided into 5 bands representing waters with a surface temperature of $2.5-3.5,3.5-4.5,4.5-5.5$, $5.5-6.5^{\circ} \mathrm{C}$, and we sought proportionality between the areas of these bands and the time spent in each band.

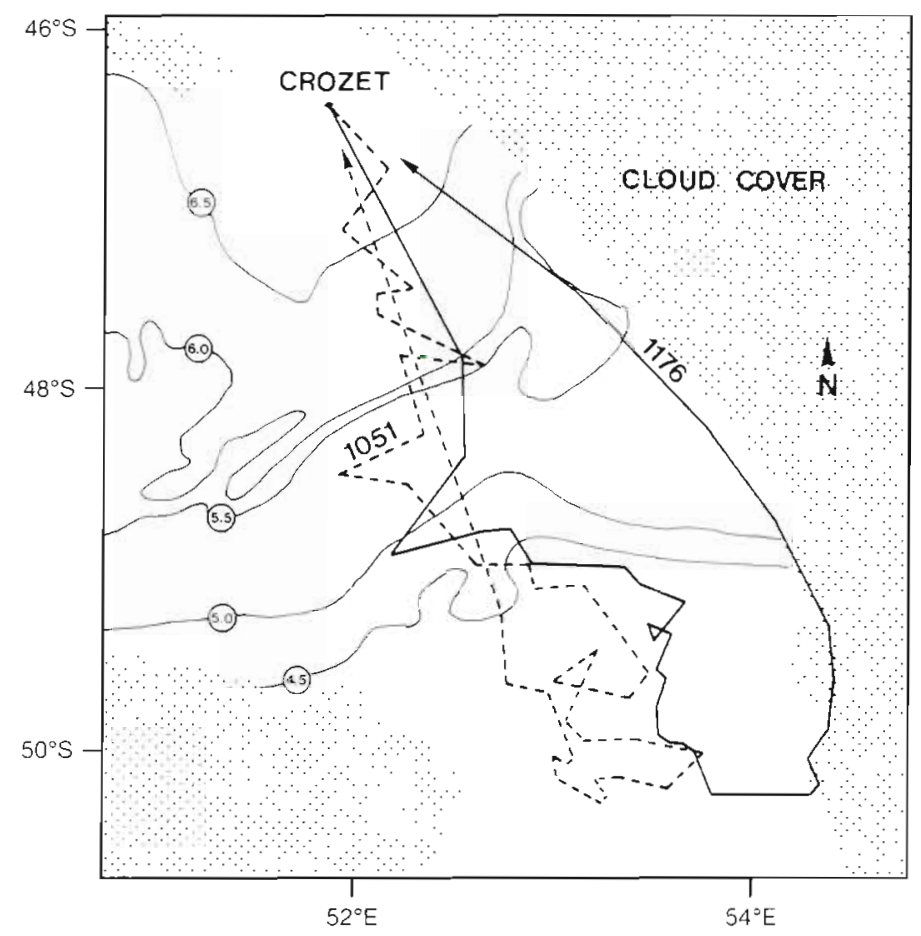

Fig. 3. Tracks of 2 king penguins (1051 and 1176) with corresponding sea-surface temperature map obtained on the 7 January 1992 from the Global Area Coverage (GAC) data obtained from the AVHRR/2 Captor on NOAA 11 satellite
Statistical analyses were done using SAS software. Continuous variables were analysed using the GLM procedure. Probabilities for statistical tests were 2tailed and the level of significance was set at $p=0.05$.

\section{RESULTS}

Over the 3 year period, distributions of sea surface temperatures for the Crozet Archipelago area in January and February were similar (Fig 2). The SubTropical and Sub-Antarctic Fronts could easily be located by a gradient of $8^{\circ} \mathrm{C}$ over 1 to 2 degrees of latitude. These 2 fronts almost merge between $45^{\circ}$ and $55^{\circ}$ E. Over the 3 years, the Sub-Antarctic Front was deflected north and reached its northernmost limit $\left(40^{\circ} \mathrm{S}\right)$ at $50^{\circ} \mathrm{E}$. The Sub-Antarctic Front moved progressively southward while the Sub-Tropical front remained at about $40^{\circ} \mathrm{S}$.

It was more difficult to locate the Polar Front, which is not characterised by a strong gradient. This structure is generally associated with a sea surface temperature of between 4 and $5^{\circ} \mathrm{C}$ (Machida 1976, Park et al. 1993). In 1992, superposition of the tracks of king penguins 1051 and 1076 on the sea surface temperature map showed that these 2 birds clearly spent a large amount of time in waters with sea surface temperatures between 4 and $4.5^{\circ} \mathrm{C}$ (Fig. 3).

Sea surface temperatures for the first week of January 1992, south of the Sub-Antarctic Front, tended to be 1 to $2^{\circ} \mathrm{C}$ cooler than in February 1993 and 1994. No major differences could be detected between February 1993 and 1994. In February 1993 and 1994 the $5^{\circ} \mathrm{C}$ and 


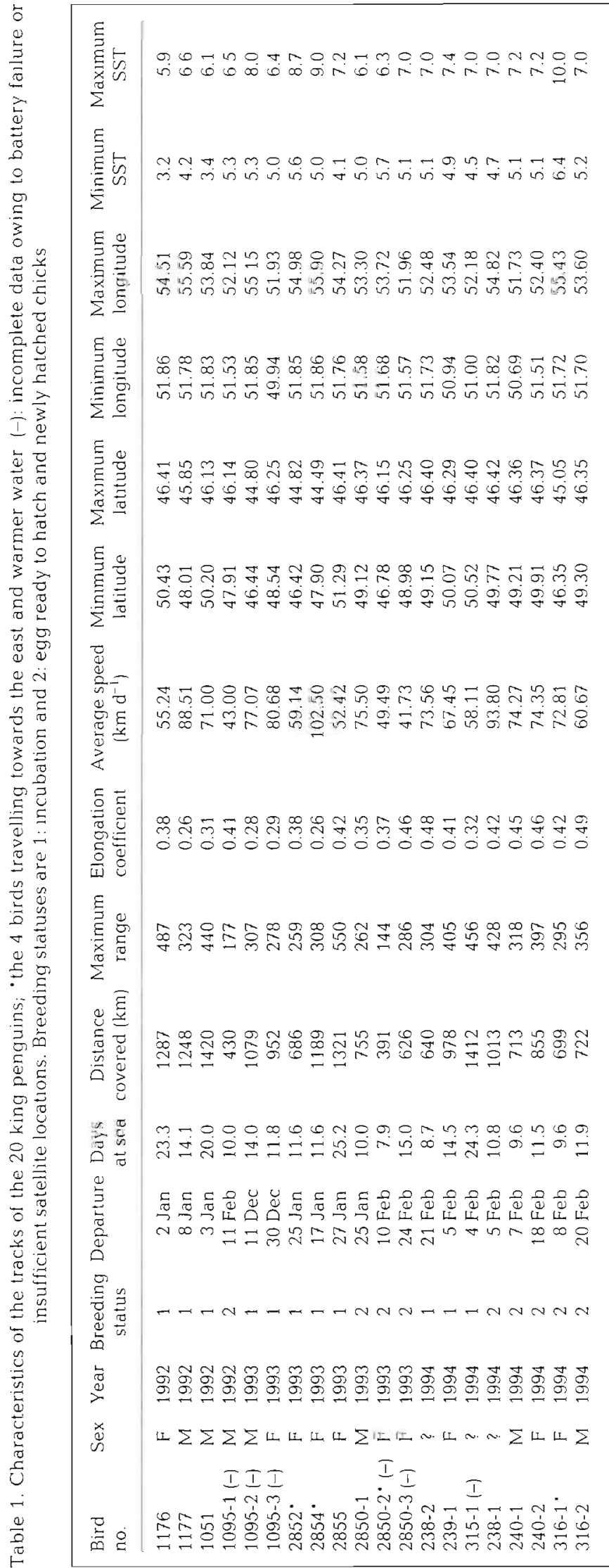

$4^{\circ} \mathrm{C}$ isotherms tended to be $2^{\circ}$ latitude further south than in January 1992.

The 20 tracked king penguins encountered sea surface temperatures between 3.2 and $10.0^{\circ} \mathrm{C}$, a temperature range of $6.8^{\circ} \mathrm{C}$ (Table 1 ). There were 2 main trends in the foraging behaviour in relation to sea surface temperature (Fig. 4). Three penguins, 2852, 2854 and 316-1, all travelled eastward and encountered an increase in sea surface temperature during the first part of the trip to maxima between 8.7 and $10.0^{\circ} \mathrm{C}$ (Table 1). In these 3 trips the king penguins were moving along the southern limit of the Sub-Antarctic Front (Fig 5); interestingly, the tracks of king penguins 2854 and 316-1 revealed a decrease in sea surface temperatures after the birds reached a maximum close to $10^{\circ} \mathrm{C}$. Among the 14 complete trips, 11 were associated with a decrease of the sea surface temperatures during the first part of the trip (Figs. 4 \& 5). Furthermore, considering the 6 remaining birds whose trips were incomplete or locations insufficient, all but $1(2850-2)$ were travelling towards colder water (Table 1). The minimum temperature reached by the 16 birds travelling toward colder waters ranged between 3.2 and $5.3^{\circ} \mathrm{C}$. The lowest temperatures (between 3.2 and $4.2^{\circ} \mathrm{C}$ ) were reached by $3(1176,1177,1051)$ out of the 4 birds tracked in 1992, and by 1 king penguin tracked in 1993 (2855); all of these birds were incubating. The remaining birds reached sea surface temperatures between 4.5 and $5.3^{\circ} \mathrm{C}$.

No effect of sex $(n=17)$ was found on any of the foraging traits studied. Breeding status (1: incubating an egg, and 2: having an egg close to hatching or a newly hatched chick) had no effect on the southward extent (maximum latitude), eastward extent (maximum longitude) or the minimum sea surface temperature encountered. The breeding status affected the time spent at sea, distance covered, the maximum range and the coefficient of elongation of the foraging trip while the year had no effect on any of these parameters (Table 2). Interestingly, while year had a significant effect on the maximum sea-surface temperature encountered by the king penguin leaving Possession Island for a trip towards colder water, we did not found any significant effect of year or of the status on the minimum temperature reached by these birds (Table 2).

The 3 incubating birds in 1992 and 1 incubating bird in 1993 spent a large amount of time in water between 4 and $5^{\circ} \mathrm{C}$ (Fig 4). Over the 3 years, the king penguins travelling southwards spent more time than expected in the coldest water of their range (Wilcoxon's signed-ranks test, $\mathrm{n}=10, Z=$ 2.60. $\mathrm{p}<0.005$ ). 
$\frac{a}{a}$
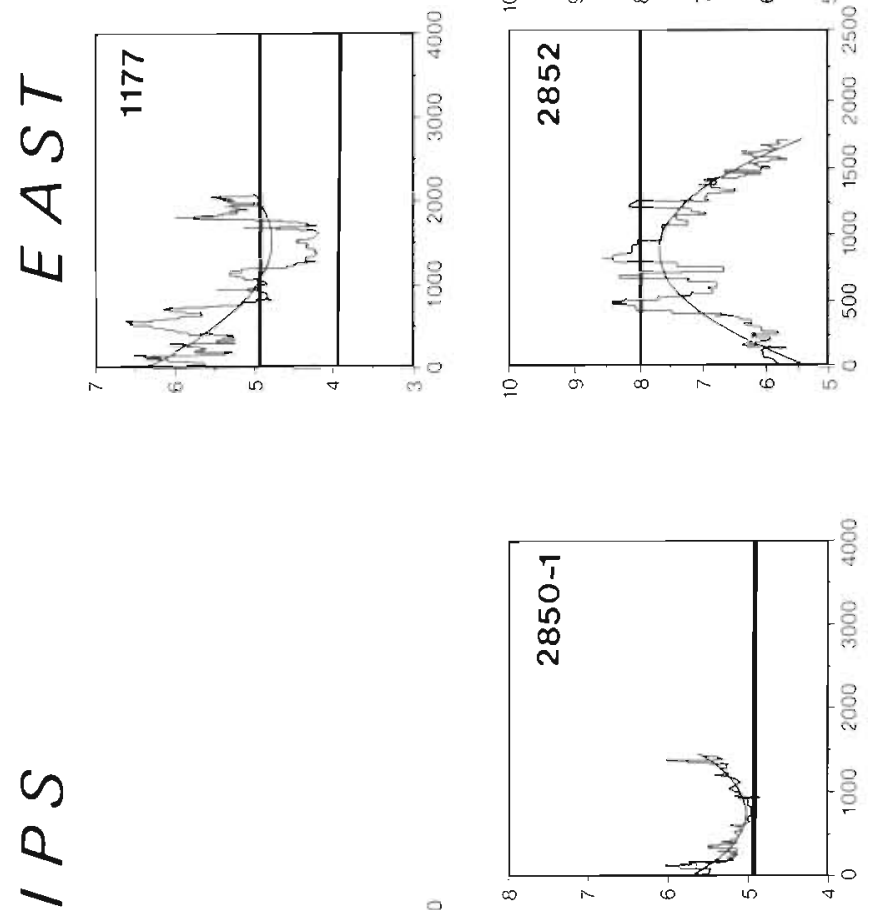

a
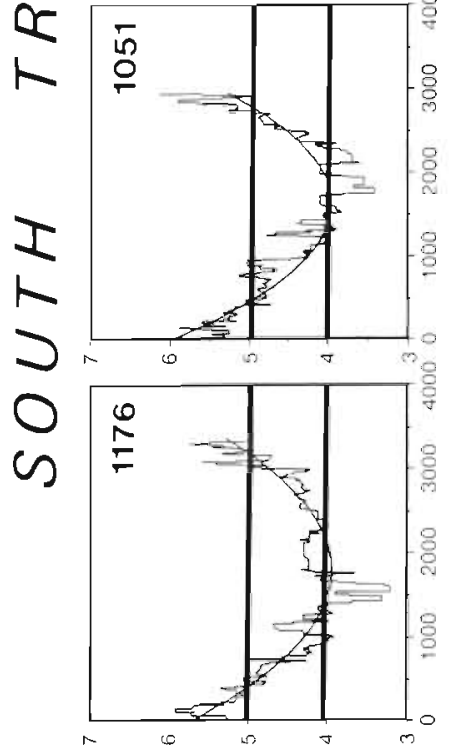

(D.) $\perp S S$

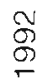
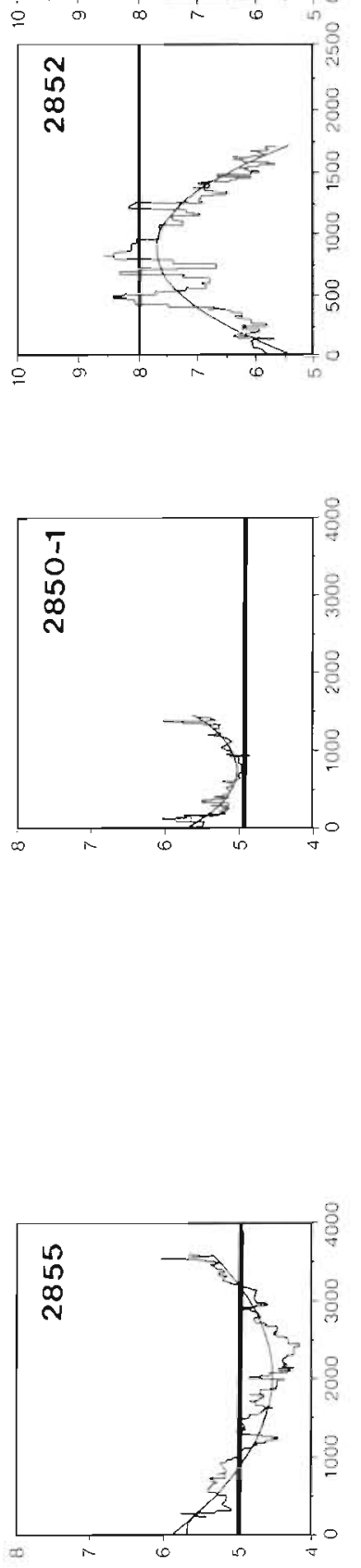

(Do) $1 S S$

\%
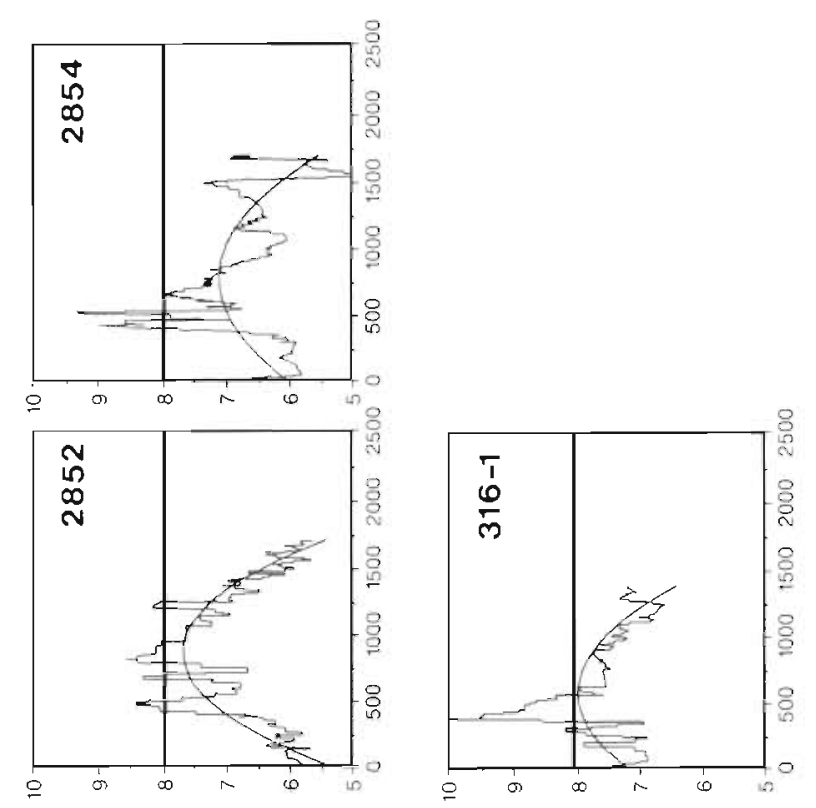

$\begin{array}{lll}5 & 5 \\ 0 & 0 & 0 \\ 0 & 0 \\ 0 & 0 \\ 0\end{array}$

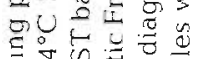

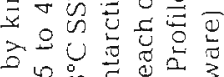

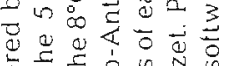

EE

亏ั

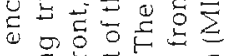

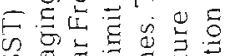

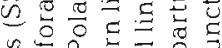

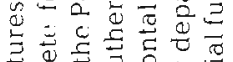

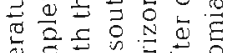

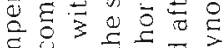

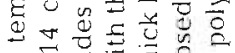

\& 0

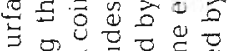

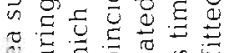

ง.

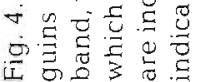
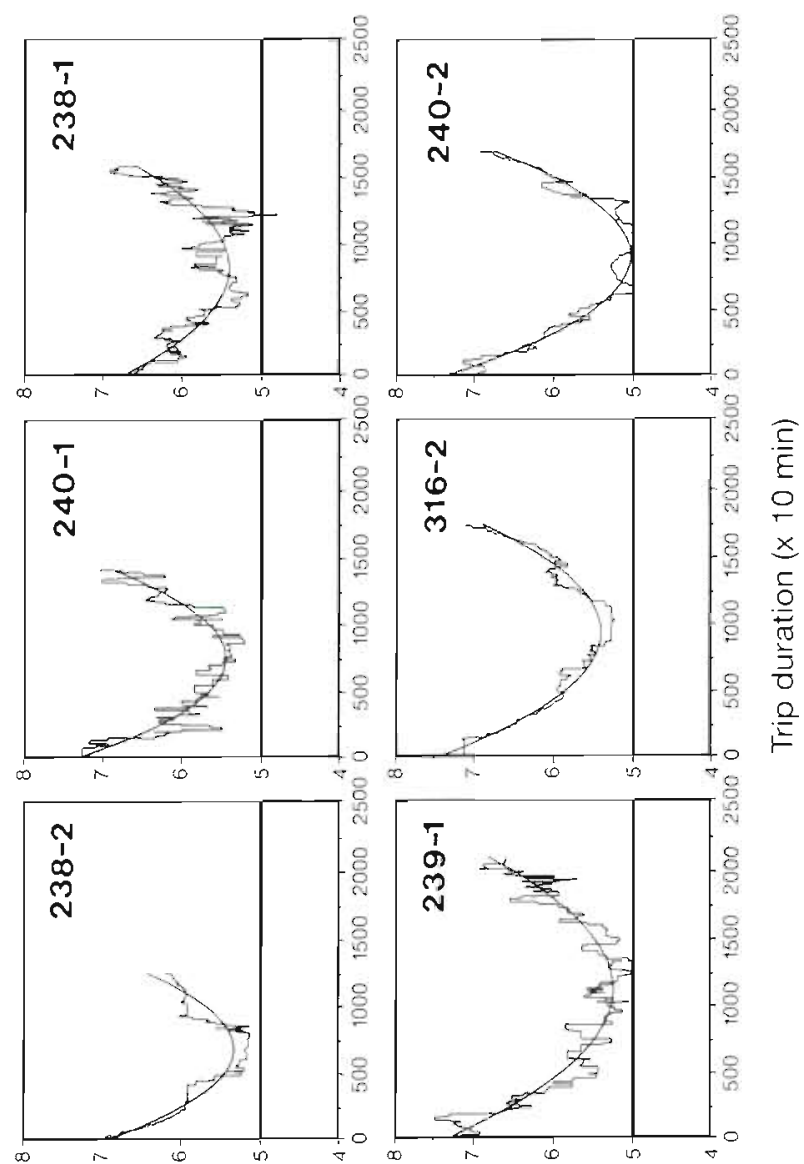

(0.) LSS

(J.) $\perp S S$

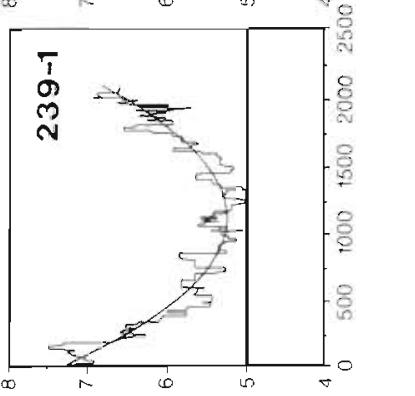

I) 

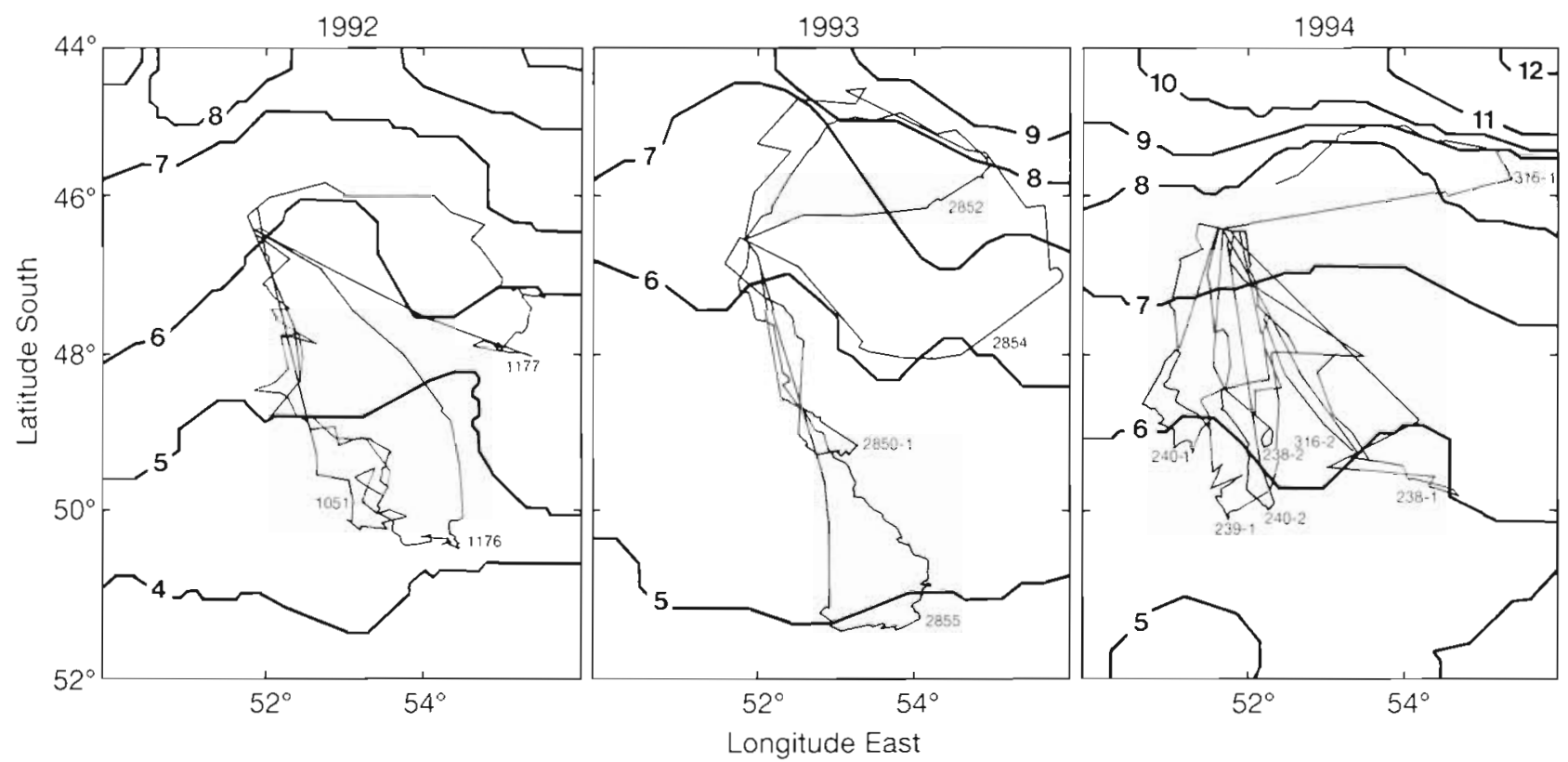

Fig. 5. Tracks of king penguins, obtained over the 3 study periods with the corresponding SST maps $\left({ }^{\circ} \mathrm{C}\right)$

\section{DISCUSSION}

Previous studies (Wilson et al, 1986) have suggested that the presence of telemetry devices may slow penguins down and thus increase trip duration or restrict the foraging range. The foraging ranges we observed were similar to those of penguins in another study, carrying miniaturised data loggers used to estimate geographic location at sea from light level data (Pütz 1994). Futhermore, compared to the data presented by Weimerskirch et al. (1992) for non-equipped birds, we did not find any evidence, as indicated by Jouventin et al. (1994), that the satellite device had an effect on the foraging trip duration during the incubation period (with a satellite device: $16.3 \pm$ $5.8 \mathrm{~d}, \mathrm{n}=11$; and without: $16.8 \pm 3.3 \mathrm{~d}$, $\left.\mathrm{n}=352 ; F_{1,361}=0.06, \mathrm{p}>0.05\right)$ How ever, during the brooding period, compared to the data presented by Weimerkirch et al. (1992), the satellite device had a significant effect on the foraging trip duration (with a satellite device: $10.7 \pm 2.0 \mathrm{~d}, \mathrm{n}=9$; and without: $7.9 \pm 2.0 \mathrm{~d}, \mathrm{n}=312 ; F_{1.319}=15.94, \mathrm{p}=$ 0.003). Bost et al. (1997) found the same relationship in 1994. Satellite tags may have a greater impact on the foraging trip duration for birds during this period when the energy require- ment is at a peak (Ricklefs 1983, Salamolard \& Weimerskirch 1993). Possibly, king penguins have to stay at sea longer to overcome the energetic cost induced by the satellite tag, but they appear to be able to compensate for that cost during the incubation.

The present study indicates that during the austral summer king penguins breeding at Possession Island

Table 2. Summaries of analyses of variance [factors: year $(1992,1993,1994)$ and status (incubating or having a newly hatched chick)] in relation to various foraging trip traits (SST: sea-surface temperature) for king penguins breeding at Possession Island, Crozet Archipelago

\begin{tabular}{|c|c|c|c|c|c|}
\hline & Factors & $\mathrm{df}$ & $\begin{array}{l}\text { Mean } \\
\text { square }\end{array}$ & $F$ & $\mathrm{p}$ \\
\hline $\begin{array}{l}\text { Minimum latitude } \\
\text { (trips toward colder waters, } n=16 \text { ) }\end{array}$ & $\begin{array}{l}\text { Year } \\
\text { Status }\end{array}$ & $\begin{array}{l}2 \\
1\end{array}$ & $\begin{array}{l}1.28 \\
0.62\end{array}$ & $\begin{array}{l}0.83 \\
0.40\end{array}$ & $\begin{array}{l}0.539 \\
0.459\end{array}$ \\
\hline $\begin{array}{l}\text { Maximum longitude } \\
\text { (trips toward colder waters, } n=16 \text { ) }\end{array}$ & $\begin{array}{l}\text { Year } \\
\text { Status }\end{array}$ & $\begin{array}{l}2 \\
1\end{array}$ & $\begin{array}{l}0.81 \\
1.82\end{array}$ & $\begin{array}{l}0.50 \\
1.13\end{array}$ & $\begin{array}{l}0.617 \\
0.309\end{array}$ \\
\hline $\begin{array}{l}\text { Minımum SST encountered } \\
\text { (trips toward colder waters, } n=16 \text { ) }\end{array}$ & $\begin{array}{l}\text { Year } \\
\text { Status }\end{array}$ & $\begin{array}{l}2 \\
1\end{array}$ & $\begin{array}{l}0.85 \\
0.98\end{array}$ & $\begin{array}{l}3.42 \\
3.96\end{array}$ & $\begin{array}{l}0.067 \\
0.070\end{array}$ \\
\hline $\begin{array}{l}\text { Maximum SST encountered } \\
\text { (trips toward colder waters, } n=16 \text { ) }\end{array}$ & $\begin{array}{l}\text { Year } \\
\text { Status }\end{array}$ & $\begin{array}{l}2 \\
1\end{array}$ & $\begin{array}{l}1.04 \\
0.00\end{array}$ & $\begin{array}{l}6.96 \\
0.00\end{array}$ & $\begin{array}{l}0.009 \\
0.980\end{array}$ \\
\hline $\begin{array}{l}\text { Days at sea } \\
\text { (all trips; } n=20 \text { ) }\end{array}$ & $\begin{array}{l}\text { Year } \\
\text { Status }\end{array}$ & $\begin{array}{l}2 \\
1\end{array}$ & $\begin{array}{r}10.61 \\
125.61\end{array}$ & $\begin{array}{l}0.48 \\
5.71\end{array}$ & $\begin{array}{l}0.620 \\
0.030\end{array}$ \\
\hline $\begin{array}{l}\text { Distance covered } \\
\text { (all trips, } n=20 \text { ) }\end{array}$ & $\begin{array}{l}\text { Year } \\
\text { Status }\end{array}$ & $\begin{array}{l}2 \\
1\end{array}$ & $\begin{array}{r}44775.33 \\
812281.33\end{array}$ & $\begin{array}{c}0.76 \\
13.81\end{array}$ & $\begin{array}{l}0.485 \\
0.002\end{array}$ \\
\hline $\begin{array}{l}\text { Maximum range } \\
\text { (all trips, } \mathrm{n}=20 \text { ) }\end{array}$ & $\begin{array}{l}\text { Year } \\
\text { Status }\end{array}$ & $\begin{array}{l}2 \\
1\end{array}$ & $\begin{array}{l}17153.72 \\
43193.50\end{array}$ & $\begin{array}{l}2.10 \\
5.30\end{array}$ & $\begin{array}{l}0.155 \\
0.030\end{array}$ \\
\hline $\begin{array}{l}\text { Average travelling speed } \\
\text { (all trips, } n=20 \text { ) }\end{array}$ & $\begin{array}{l}\text { Year } \\
\text { Status }\end{array}$ & $\begin{array}{l}2 \\
1\end{array}$ & $\begin{array}{l}358.00 \\
163.53\end{array}$ & $\begin{array}{l}1.28 \\
0.58\end{array}$ & $\begin{array}{l}0.275 \\
0.569\end{array}$ \\
\hline $\begin{array}{l}\text { Elongation coefficient } \\
\text { (all trips, } \mathrm{n}=20 \text { ) }\end{array}$ & $\begin{array}{l}\text { Year } \\
\text { Status }\end{array}$ & $\begin{array}{l}2 \\
1\end{array}$ & $\begin{array}{l}0.01 \\
0.02\end{array}$ & $\begin{array}{l}2.95 \\
5.43\end{array}$ & $\begin{array}{l}0.081 \\
0.030\end{array}$ \\
\hline
\end{tabular}


have 2 alternative foraging strategies in relation to the sea surface temperatures. One is to travel towards warmer waters $\left(8\right.$ to $10^{\circ} \mathrm{C}$; Figs. $\left.4 \& 5\right)$, which correspond to the southern limit of the Sub-Antarctic Front (Lutjerharms \& Valentine 1984) and the northern limit of the foraging range of king penguins in summer The 4 king penguins passing through warmer water during the first part of their joumey were all travelling east and 3 of them reached the Sub-Antarctic Front northeast of the Crozet Archipelago, which was also the most frequented area by these birds (see Bost et al. 1997). In this location the front reverts to $43-44^{\circ} \mathrm{S}$ along the northern border of the Crozet plateau after being deflected north by the Crozet shelf. Stahl et al. (1985), observing from ships, never saw king penguins north of $43^{\circ} \mathrm{S}$ in the Crozet region, which generally coincides with the northern limit of the Transition Frontal Zone (Park et al. 1991, 1993; Fig. 1).

The most frequently observed category of foraging trip $(80 \%)$ was characterised by a decrease of the sea surface temperatures under the track of king penguins leaving their breeding colony. Most of these trips were oriented due south.

Why birds should head eastward towards the SubAntarctic Front rather than southward towards the Polar Front is not yet understood. Birds appear to travel in both directions regardless of their breeding stage but the sample size is too limited to investigate this point. We could not confirm the contention of Jouventin et al. (1994) that males tended to travel more frequently towards the east.

The breeding status of the bird affected most of the foraging traits studied. Incubating birds have foraging trips which were on average $60 \%$ longer than birds having an egg close to hatching or a newly hatched chick. However, we found no evidence that incubating birds, despite longer periods at sea and longer foraging trips, went further south to reach colder sea surface temperatures compared to king penguins having an egg ready to hatch or a newly hatched chick. Early in the breeding season incubating birds were able to reach sea surface temperatures associated with the Polar Front. These birds spent enough time at sea to go further south than the Polar Front, but were not observed to do so; these birds tended to concentrate their time in water with sea surface temperatures associated with the Polar Front.

Birds at the end of incubation or during brooding confront 2 limiting factors: (1) the time these birds can spent at sea is limited by the fasting abilities of the chicks, which are unlikely to survive if more than 10 to $14 \mathrm{~d}$ elapse between feeds; thus there is a major biological constraint at this stage; (2) as the summer progresses, the Polar Front moves south (Jacques \& Treguer 1986, Nagata et al. 1988) to reach its southern- most position by the end of February (Deacon 1982). King penguins with a newly hatched chick seem to compensate partly for the limited time they can spend at sea by travelling more directly (higher elongation. coefficient), but not more rapidly towards the colder southern waters.

Our study indicates that during the austral summer, the king penguins of Possession Island forage within the Polar Frontal Zone. The summer diet of these birds at Crozet Archipelago also supports this finding (Ridoux 1994, see Bost et al. 1997). Within the Polar Frontal Zone, king penguins favoured 2 main locations associated either with the Polar Front and its northern limit or the Sub-Antarctic Front. In comparison, in winter, breeding king penguins were observed to go as far as $65^{\circ} \mathrm{S}$, thus reaching the limit of the pack ice (Jouventin et al. 1994).

The distribution of king penguins within the Polar Frontal Zone and their foraging activity (see Bost et al. 1997) can be related to the biogeography of their main prey, the myctophid fish, which are distributed through the whole Polar Frontal Zone but which are more abundant in the frontal regions (Pakhomov et al. 1994). King penguins feed mainly on the truly oceanic species of lanternfish (Krefftithys anderssoni, Protomyctophum sp. and Electrona carlsbergi; Klages et al. 1990, Kooyman et al. 1992, Pütz \& Bost 1994, Bost et al. 1997). Interestingly, these myctophids are generally associated with water masses of between 4 and $5^{\circ} \mathrm{C}$ (Hulley 1981). Throughout the Polar Frontal Zone, these cold surface waters sink progressively under warmer, less dense waters along a south-north transect from the Polar Front to the Sub-Antarctic Front (Deacon 1982, Lutjeharms 1985, Park et al. 1991; Fig. 1). Thus, the myctophids associated with these water masses are likely to progressively become out of diving range of the king penguins.

Pakhomov et al. (1994) indicated that myctophids dominated the fish biomass community at both fronts. Their biomass was higher in summer in the Tropical Frontal Zone (Fig. 1) compared to the Polar Front. However, while myctophids could be fished during the day between 0 and $300 \mathrm{~m}$ in the Polar Front region, they were only accessible at night in the Sub-Antarctic Front between 0 and $300 \mathrm{~m}$, which does not suit king penguins, for whom deep diving and most of the food intake take place during the day (Pütz \& Bost 1994). Several authors have also stressed that, while the seasonal influence on the productivity of the Polar Front region is very marked (El-Sayed 1988, Semelinka 1993), productivity of the Sub-Antarctic Front tends to be uniform throughout the year (Allanson et al. 1985, Comiso et al. 1993. Weeks \& Shillington 1994). As the 2 fronts are at approximately the same distances from the Crozet Islands, king penguins may choose between 2 alternative 
strategies, namely to forage towards the Sub-Antarctic Front with its abundant but less accessible myctophid community or to travel towards the Polar Front where a large but seasonally variable biomass of myctophids is accessible. Heading toward the Polar Front may also allow the king penguins to reduce their diving effort as the myctophids are at shallower depths.

The frontal zones, major contributors to the production of the Southern Ocean (Allanson et al. 1985, Lutjeharms 1985, El-Sayed 1988), appear to play a key role in the summer foraging activity of king penguins as in many other seabirds. Our findings are consistent with previous studies on the pelagic distribution of seabirds obtained along ship transects crossing the main circumpolar frontal zones of the Southern Ocean. Enhancement of the activity and abundance of birds and marine mammals in the proximity of the Southern Ocean fronts, and in particular in the Polar Front region, is well recorded (Batytskaja \& Shurunov 1983, Abrams 1985b, Stahl et al. 1985, Hunt'1990, 1991, Pakhomov \& McQuaid 1996). Ainley et al. (1984) on a ship transect conducted in February in the Ross Sea found juvenile king penguins in water with a sea surface temperature of $4.5^{\circ} \mathrm{C}$, which can be associated with the location of the Polar Front. In our study, satellite-tracked king penguins reached and spent a large amount of time in water associated with a frontal zone, which supports the hypothesis that in the oceanic frontal regions seabirds concentrate at the sea surface temperature signature of the fronts (Abrams 1985b). Our study also shows that bird species such as the Crozet king penguins which consume a very large amount of prey (Guinet et al. 1996) tend to concentrate their foraging activity in the most productive parts of the Southern Ocean

King penguins also breed in localities south of the Polar Front, such as South Georgia and Heard Island. We predict that these king penguins will tend to travel north to reach the Polar Front. Furthermore, if the distribution at sea of king penguins can be related to the position of the Polar Front, we expect that demographic parameters such as reproductive rates, hatching success and body condition can be related to the position of the Polar Front, which may be more or less (further south) accessible in relation to year-to-year oceanographic changes.

Acknowledgements. We thank Line Jouventin-Ruchon for making the figures and Martine Lacalle for making the tables. We thank C. Boiteau, F. Cuenot-Chaillet, S. Eudes, F. Lagarde, E. Valentini and K. Pütz for their assistance in the field. We thank S. Hall for correcting the English. Three anonymous referees made helpful comments on an earlier draft of the manuscript. This work was supported by the Institut Français de la Recherche et Technologie Polaire and by the programme bio-indicators of the Groupement de Recherche 'ecosystèmes polaires et anthropisation'

\section{LITERATURE CITED}

Abrams RW (1985a) Energy and food requirement of pelagic aerial seabirds in different regions of the African sector of the southern Ocean. In: Siegfried WR, Condy PR, Laws RM (eds) Antarctic nutrient cycles and food webs. Springer-Verlag, Berlin, p 466-472

Abrams RW (1985b) Environmental determinant of pelagic seabird distribution in the African sector of the Southern Ocean. J Biogeogr 12:473-492

Ainley DG, Jacobs SS (1981) Seabirds affınities for ocean and irr boundaries in the Antarctic. Deep Sea Res 28: $1173-1185$

Ainley DG, O'Connor EF, Boekelheide RJ (1984) The marine ecology of birds in the Ross Sea, Antarctica. Ornithol Monogr 32:1-97

Allanson BR, Broden B, Parker L, Duncombe Rae C (1985) A contribution to the oceanology of the Prince Edward Islands. In: Siegfrued WR, Condy PR, Laws RM (eds) Antarctic nutrients cycles and food webs. Springer-Verlag, Berlin, p 38-45

Batytskaja LV, Shurunov NA (1983) Distribution of seabirds in the Southern Ocean with the connection of the distribution of water masses during austral summer. J Zool 62:755-760

Comiso JC, MCClain CR, Sullivan CW, Ryan JP, Leonard CL (1993) Coastal zone color pigment concentrations in the Southern Ocean and relationships to geophysical surface features. J Geophys Res 98:2419-2451

Deacon GER (1982) Kerguelen, Antarctic and Subantarctic. Deep Sea Res 30:77-81

Elphick CS, Hunt GL (1993) Varation in the distributions of marne birds with water mass in the northern Bering Sea. Condor 95:33-44

El-Sayed SZ (1988) Seasonal and interannual variabilities in Antarctic phytoplankton with reference to krill distribution. In: Sahrage D (ed) Antarctic Ocean and resources varlability. Springer-Verlag, Berlin, p 101-119

Gamberoni L, Geronimi J, Jeannin PF, Murail JF (1982) Study of frontal zones in the Crozet-Kerguelen region. Oceanologica Acta 5:289-299

Guinet C, Cherel Y, Ridoux V, Jouventin P (1996) Consumption of marine resources by seabirds and marine mammals at Crozet and Kerguelen Islands: changes in relation to consumer biomass trends over the last decades. Antarct Scl 8:23-30

Guinet C, Jouventin P. Malacamp J (1995) Satellite remote sensing in monitoring change of seabirds: use of Spot Image in king penguin population increase at lle aux Cochons, Crozet Archipelago. Polar Biol 15:511-515

Hulley PA (1981) Results of the research cruise of FRV 'Walter Herwig' to South America. LVIII. Family Myctophidae (Osteichthyes Myctophiformes). In: Tiews K, Sahrhage D (eds) Archiv für Fischereiwissenschaft, Vol 42. Heenemann Verlag, Berlin, p $1-300$

Hunt GL (1990) The pelagic distribution of marine birds in an heterogenous environment. Polar Res 8:43-54

Hunt GL (1991) Occurrence of polar seabirds at sea in relation to prey concentration and oceanographic factors. Polar Res 10:553-559

Hunt GL, Priddle J, Whitehouse MJ, Veit RR, Heywood RB (1992) Changes in the seabird species abundance near south Georgia during a period of rapid change in sea surface temperature. Antarct Sci 4:15-22

Jacques G. Treguer P (1986) L'Océan Antarctique. Ecosystemes pélagiques marins. Masson, Paris

Jouventin P, Capdeville D. Cuenot-Chaillet F, Boiteau C (1994) Exploitation of pelagic resources by a non-flying 
seabird: satellite tracking of the king penguin throughout the breeding cycle. Mar Ecol Prog Ser 106:11-19

Klages NTW, Pemberton D, Gales RP (1990) The diets of king and gentoo penguins at Heard Island. Aust Wildl Res 17 $53-60$

Kooyman GL, Cherel Y, LeMaho Y, Croxall JP, Thorson PH Ridoux V. Kooyman CA (1992) Diving behavior and energetics during foraging cycles in king penguins. Ecol Monogr 62:143-163

Kooyman GL, Davis RW (1987) Diving behavior and performance, with special reference to penguins. In: Croxall JP (ed) Seabirds feeding ecology and role in marine ecosystems. Cambridge University Press, Cambridge, p 63-75

Lutjerharms JRE (1985) Location of frontal systems between Africa and Antdrctica: some preliminary results. Deep Sea Res 32:1459-1509

Lutjeharms JRE, Valentine HR (1984) Southern Ocean thermal fronts south of Africa. Deep Sea Res 31:1461-1475

Machida S (1976) Surface temperature field in the Crozet and Kerguelen whaling grounds. Sci Rep Whales Res Inst Tokyo 26:271-287

Nagata Y, Michida Y, Umimura Y (1988) Variation of positions and structures of the oceanic fronts in the Indian ocean sector of the southern ocean in the period from 1965 to 1987. In: Sahrage D (ed) Antarctic Ocean and resources variability. Springer-Verlag, Berlin, p 92-98

Pakhomov EA, MCQuaid CD (1996) Distribution of. surface zooplankton and seaburds across the Southern Ocean. Polar Biol 16:271-286

Pakhomov EA, Perissinotto R, McQuaid CD (1994) Comparative structure of the macrozooplankton micronekton communities of the subtropical and Antarctic polar fronts. Mar Ecol Prog Ser 111:155-169

Park YH, Gamberoni L, Charriaud E (1991) Frontal structure and transport of the Antarctic Circumpolar Current in the Southem Indian Ocean sector, 40-80 ${ }^{\circ} \mathrm{E}$. Mar Chem 35 $45-62$

Park YH, Gamberoni L, Charriaud E (1993) Frontal structure water masses, and circulation in the Crozet basin. J Geophys Res 98:12361-12385

Power JH, Nelson May L (1991) Satellite observed seasurface temperatures and yellowfin tuna catch and effort in the Gulf of Mexico. Fish Bull US 89:429-439

Pütz K (1994) Untersuchungen zur Ernährungsökologie von Kaiserpinguinen (Aptenodytes fosteri) and Konigspinguinen (Aptenodytes patagonicus). Benchte zur Polar-

This article was submitted to the editor forschung 136, Alfred Wegener Institut für Polar- und Meeresforschung, Bremerhaven

Pütz K, Bost CA (1994) Feeding behaviour of free ranging king penquins (Aptenodytes patagonicus). Ecology 75: $489-497$

Ricklefs RE (1983) Some considerations on the reproductive energetics of pelagic seabirds. Stud Avian Biol 8:84-94

Ridoux $V^{\prime}(1994)$ The diels and dietary segregation of seabirds at the subantarctic Crozet Islands. Mar Ornithol 22:1-192

Salamolard M. Welmerskirch H (1993) Relationshıp between foraging effort and energy requirement throughout the breeding season in the wandering albatross. Funct Ecol $7: 643-652$

Semelkina AN (1993) Development of the zooplankton in the Kerguelen lslands region in the years $1987-88$. In: Duhamel $G$ (ed) Les rapports des campagnes à la mer campagnes SKALP 1987 et 1988 aux îles Kerguelen à bord des navires 'SKIFF' et 'KALPER' 93-01 Terres Australes et Antarctiques Françaises, Paris, p 90-103

Stahl JC, Jouventin P, Mougin JL, Roux JP, Weimerskurch H (1985) The foraging zones of seabirds in the Crozet Islands sector of the Southern Ocean. In: Siegfried WR, Condy R, Laws RM (eds) Antarctic nutrient cycles and food webs Springer-i'srlag, Berlın, p 478-486

Thomiz: AC, Emery WJ (1988) Relationships between near surface plankton concentration, hydrography, and satellite-measured sea surface temperature. J Geophys Res 93(C): $15733-15748$

Weavers BW (1992) Seasonal foraging ranges and travels at sea of little penguins Eudyptula minor, determined by radiotracking. Emu 91:302-307

Weeks SJ. Shillington FA (1994) Interannual scales of variation of chorophyll concentrations from the CZCS data in the Benguela upwell.ng system and subtropical convergence south of Africa. J Geophys Res 99(C4):7385-7399

Weimerskirch H, Stahl JC, Jouventin P (1992) The breeding biology and population dynamics of king penguins Aptenodytes patagonica on the Crozet Islands. Ibis 134: $107-117$

Weimerskirch H, Wilson RP, Guinet C, Koudil M (1995) The use of seabirds to monitor sea surface temperature and valıdate satellite remote-sensing measures in southern ocean. Mar Ecol Prog Ser 126:299-303

Wilson RP, Grant WS, Duffy DC (1986). Recording devices on free ranging marine animals: does measurement affect performance? Ecology 67:1091-1093

Manuscript first received: October 11, 1995

Revised version accepted: November 11, 1996 